\title{
EchoGéo
}

$47 \mid 2019$

Nouvelles géographies de la collecte

\section{Wild medicinal plant collection in transitional societies: A case Analysis from French Guiana}

Marc-Alexandre Tareau, Lucie Dejouhanet, Guillaume Odonne, Marianne Palisse and Clarisse Ansoe

\section{(2) OpenEdition \\ Journals}

Electronic version

URL: https://journals.openedition.org/echogeo/17260

DOI: 10.4000/echogeo.17260

ISSN: 1963-1197

Publisher

Pôle de recherche pour l'organisation et la diffusion de l'information géographique (CNRS UMR 8586)

\section{Electronic reference}

Marc-Alexandre Tareau, Lucie Dejouhanet, Guillaume Odonne, Marianne Palisse and Clarisse Ansoe, "Wild medicinal plant collection in transitional societies: A case Analysis from French Guiana", EchoGéo [Online], 47 | 2019, Online since 21 April 2019, connection on 10 August 2021. URL: http:// journals.openedition.org/echogeo/17260 ; DOI: https://doi.org/10.4000/echogeo.17260

\section{This text was automatically generated on 10 August 2021}

EchoGéo est mis à disposition selon les termes de la licence Creative Commons Attribution - Pas d'Utilisation Commerciale - Pas de Modification 4.0 International (CC BY-NC-ND) 


\title{
Wild medicinal plant collection in transitional societies: A case Analysis from French Guiana
}

\author{
Marc-Alexandre Tareau, Lucie Dejouhanet, Guillaume Odonne, Marianne \\ Palisse and Clarisse Ansoe
}

Acknowledgements: We thank the Mama Bobi Association for its advice and support in SaintLaurent-du-Maroni, to the inhabitants of Sosoité, Santi Pasi and Cayenne, and to everyone whom we met during our research trips who willingly talked to us about the armfuls of plants they were carrying.

This work was partly funded by grants from Labex CEBA (ANR-10-LABX-25-01, from the French National Research Agency) and its ReKABioS project. It received support from the OyaMar project financed by French Guiana ERDF. It also forms part of the EA 929 AIHP-GEODE project: "Urban territories: from the Antilles archipelago to the Guiana Shield: spaces, societies and relationships (16th-21st centuries)", and the doctoral thesis by Marc-Alexandre Tareau.

Translation from French by InPuzzle

\section{Introduction}

"There's nothing in these woods. People jogging, prostitutes, people taking their dogs for a pee, and maybe a few people collecting plants." This comment, made by a manager of a town planning agency in French Guiana whom we interviewed, accurately shows how the uninitiated view the collection of medicinal plants in Guiana: a practice which is little known, underestimated and often seen as incidental or even unimportant. Yet every day, you come across people picking plants on roadsides all along the coast of Guiana in both the urban and rural environments, to meet their own herbal medicine needs or, to a lesser extent, to sell them. Moreover, around $60 \%$ of the medicinal plants consumed by inhabitants living along the Guiana coastline are collected this way (unpublished data taken from M-A Tareau's ongoing doctoral thesis). But the dividing line separating the wild from the domesticated, long-evident in Europe 


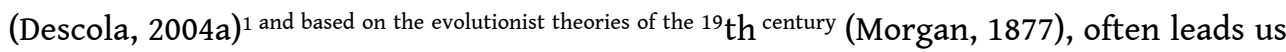
to perceive plant collection as a relic of the past, so we ignore the complexity and diversity of the constant interactions between societies and plant life (GarineWichatitsky, 1997).

In order to understand how these overlooked practices are organised we decided to study them in French Guiana, a place where multiculturalism, demographic growth and major migratory flows have left their mark (Piantoni, 2011). The aim of this paper is to characterise these medicinal plant gathering practices, to understand their diversity, and also to understand their relevance for examining how transitional societies operate. These societies are marked by major rural exodus, rapid transformation of their socio-cultural structures and living environment, and by the increasingly significant cohabitation of groups with differing origins and differing approaches to nature.

This research was produced using multiple methods implemented from January 2016 to April 2018. Semi-structured interviews were carried out in Cayenne and in the LowMaroni region bordering Suriname with different members of the population in these regions (illustration 1). We also interviewed vendors of aromatic and medicinal plants, collected over 300 herbarium samples and took them to Cayenne Herbarium (CAY Herbarium from the Institut de Recherche pour le Developpement) ${ }^{2}$, and were able to draw up a spatial distribution map of plant gathering by accompanying gatherers to their collection sites. For our analysis of the position occupied by collection in transitional Guianese society, we present two case studies: urban collection in the city of Cayenne by different populations, and medicinal plant collection in the Low-Maroni region by peoples of the Ndjuka ethnic group. Collection activities by these populations are distributed in space using a structure of "circles", the specific features of which can still be seen in a variant form in urban settings. So using the Guianese situation, we offer a conceptualization of types of collection based on their spatial distribution and introducing the concepts of "heterogeneity" and "purpose" as factors explaining these practices. 


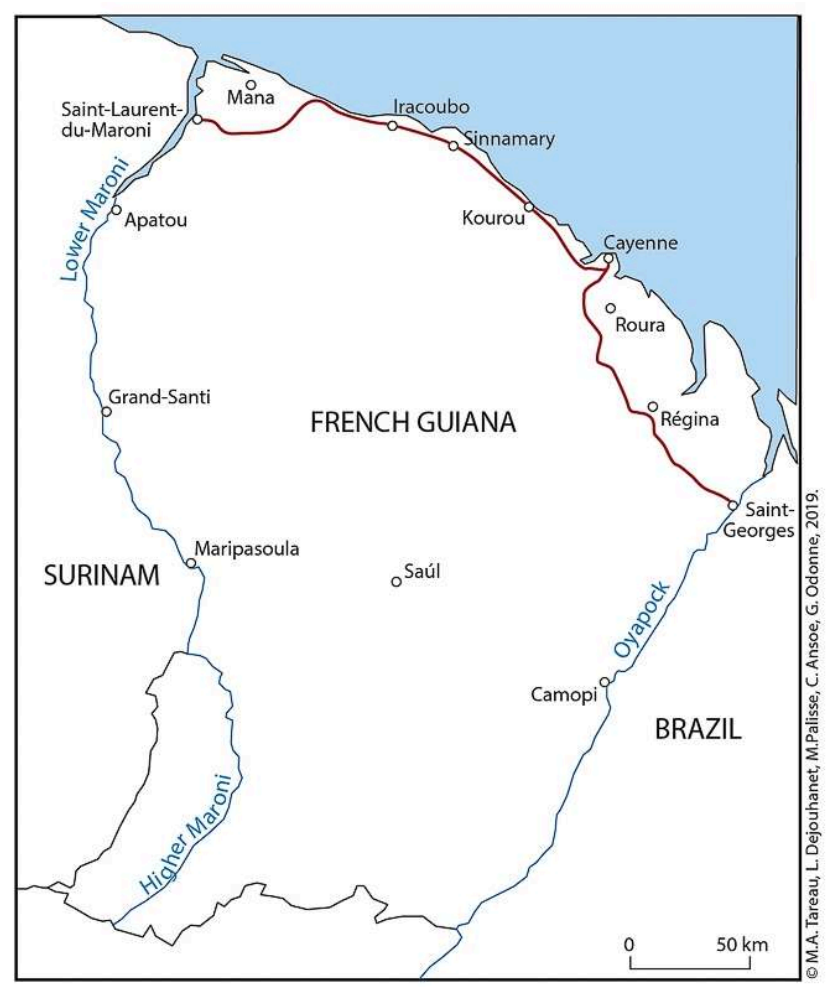

\section{From village to town: French Guiana, a transitional society}

French Guiana is characterised by its complex settlement history, which has given rise to extensive cultural diversity. After its colonial conquest, this country became a space shared by European, Amerindian and Maroon populations (resistance fighters and slaves who had run away from Suriname plantations in the $17^{\text {th }}$ and $18^{\text {th }}$ centuries), and by a Creole population (Afro-Americans born during and after slavery). In the $19^{\text {th }}$ century, the latter group incorporated various immigration-related features into their lifestyle. Immigration is ongoing in French Guiana, but it was in the 1970's that voluntary immigration into French Guiana became really sizeable. Immigrants come primarily from Brazil, Haiti and Suriname, but also from other Latin American countries and from Asia (Piantoni, 2011). At the same time, there are diverse population movements within Guiana itself. Since the 1950's, the government had been trying to regroup and settle the Amerindian and Maroon populations (Guyon, 2011). A significant rural exodus is also under way (Jolivet, 1982), in part linked to decentralised construction sites and space exploration bases, and we are also witnessing the spectacular expansion of Cayenne, Kourou and Saint-Laurent-du-Maroni conurbations, the latter receiving a massive influx of refugees as a result of the civil war in Suriname (1986-1992). A feature of these urban clusters is their highly diverse populations, which sometimes group together in neighbourhoods whose residents share the same ethnic origin and who often maintain ties with their original region, going back and forth between town and countryside. Some of these populations have French citizenship, whilst others face the problems of their immigrant condition and the difficulty of 
obtaining legal status. In spite of being relatively compartmentalised, the urban phenomenon gives rise to forms of hybridisation between populations who have different ways of living, connecting to their bodies and connecting to the environment. This is the backdrop to the development of new relationships with plant life and the emergence of new ways of collecting plants.

\section{The need for nature in towns: finding useful plants in Cayenne}

Cayenne is the capital of French Guiana and its administrative and economic hub. Taken with its adjacent municipalities, it forms a conurbation with a population numbering 109,538 (INSEE French National Institute for Statistics and Economic Research, 2014), i.e. just under half of the Department's total population. It is the hub where most government activities and services are concentrated. Residential and business areas in the city of Cayenne are growing and becoming denser across the conurbation, although there are some pockets of greenery in the form of "knolls" 3 and pripri ${ }^{4}$ dotted across the urban expanse. The rural exodus and migratory flows have swelled the population of Cayenne city considerably over recent decades (Jolivet, 1982; Piantoni, 2011). In 2005, 30\% of the total population of French Guiana was of immigrant origin $^{5}$ (Hurpeau, 2012), often living in precarious conditions in underprivileged neighbourhoods that sprang up out of nowhere (Auburtin, 2007, 2006; Gardel, 2001; Gorgeon, 1985; Romanovski \& Piantoni, 2009). It is primarily to meet their primary care needs that urban populations collect certain medicinal plants from their surroundings, partially offsetting the difficulties they have in accessing conventional medicine (Carde, 2006; Jolivet, 1982; Valmy et al., 2015). In developing cities like Cayenne, its inhabitants maintain the herbal remedy and plant collection practices of their original cultures (Tareau et al., 2017). These practices thus act as markers of cultural identity (Volpato et al., 2008) - a real "identity and culture reflex" (Benoitt, 2007) - and as a link with the regions where people originally come from (Bourdeau-Lepage \& Vidal, 2012), and as a way of integrating these groups in the city (Roulleau-Berger \& Lu, 2003).

The different groups living in Cayenne have made its urban spaces their own, finding the spots where useful plants grow and making use of their trips to and fro to collect particular varieties, drawing up mental maps of the city and its potential collection sites. Green roadside verges, urban wastelands and empty plots are favourite collection spots: these environments, termed "degraded" are undeveloped and of undeniable ecological value in terms of flora diversity and density (Sukopp \& Hejny, 1990), because it is here that wild vegetation, able to adapt to the urban environment conditions, grows (Arnould et al., 2011). They are "refuges of biodiversity" (Clément et al., 2004). Urban parks and suburban woodlands are also places where medicinal varieties are collected, just like in other parts of the world (Bussmann \& Sharon, 2009; Landy et al., 2017; Nguenang et al., 2010; Wehi \& Wehi, 2010). Lastly, cultivated plants that spread beyond urban gardens onto the streets are also much picked by pedestrian passers-by. All of these branches, which find their way outside private spaces, become part of a large, shared garden. Towns thus offer many opportunities for picking, often in spite of urban planning policies which aim to clean up the suburbs and confine nature to managed green spaces, whether public or private (Baudry, 2015).

Furthermore, towns and cities in Guiana have particular landscapes resulting from the specificities of their growth. These "transitional towns" (Wiel, 1999) are made up of mosaics of widely differing districts: unplanned quarters, planned settlements, 
wetlands or forest areas, grand residences and buildings from the colonial period, all rub shoulders in the urban environment. Urban planning and development often lags behind rapid, disorganised urbanisation. New suburban neighbourhoods are spreading out into the rural spaces around towns, but town and city centres are becoming more densely developed and populated. Even in Cayenne, the gradient model of land degradation from the centre outwards to the suburbs (Arnould \& Cieslak, 2004) applies, and brings with it a "collection gradient" which diminishes as the built environment densifies. The creole gardens typical of the old centre of Cayenne have been progressively obliterated by constructions and the tendency for these green spaces to get "closed down" continues. The use of herbicides and the "maintenance" of roadsides which are regularly and fairly systematically cut back also limit the collection options in urban centres. However, in working class suburban districts useful plants that grow wild are protected, as a Haitian resident tells us:

Anvil yo ka rache se zeb la, yo ka gaze yo, nou nou konnèt yo donk nou ka kite yo (Haitian creole. "In the town, they pull up these plants, they 'gas' them, but us, we know what they are so we protect them").

The different cultural groups that live in Cayenne give rise to overlapping collection practices which differ according to the socio-cultural specificities of these groups. So, Guianese Creoles have an in-depth knowledge of plants and can move around easily, given their relatively high living standards; by contrast they have relatively little need to use these plants for healthcare purposes, because they have access to all the structures of the French healthcare system. So they collect plants more for convenience and for treating minor ailments. At the other end of the scale, illegal Haitian immigrants have great need of wild plants because of their limited access to hospitals; by contrast they cannot move around easily and have to settle for the plants they can find in their district or nearby. Haitians are not necessarily familiar with Guianese wild plants and prefer cultivated ones whose seeds they can bring from Haiti, or they find local varieties similar to the ones they know. Certain easily identifiable wild plants are also used: this is the case of $a s o s i^{6}$, Momordica charantia, a pan-tropical gourd of Indian origin which grows wild along fences or on wasteland (illustration 2). Consuming asosi is a very widespread practice among Haitians, who macerate its leaves in rum. Although there is a cultivated variety grown for its vegetables, it is exclusively the wild variety with bitter leaves that is used for preparing the eponymous beverage ${ }^{7}$. Lianas are therefore protected by Haitians, and their presence has become a plant marker of Haitian neighbourhoods:

Asosi se on bagay ki leve tousèl, nou pa plante'l. Alò se pousa lè nou wèy nou ka

kite'y pou nou pe sa trape lè nou bizwen prepare boutey asosi yo ("Asosi is a plant which grows all by itself, you don't need to plant it. That's why whenever you see it, you keep it so you have some for making bottles of asosi").

These differentiation phenomena in cultural practices and their spatial distribution are echoed in the "urban ecology" theories developed by sociologists and geographers from the School of Chicago (Grafmeyer \& Joseph, 1984), who were already showing back in the 1920's and 30's how neo-immigrants settle in conurbations according to a process of regrouping and segregation based on the diversity of their socio-cultural roots (Burgess, 1929 ; Park et al., 1984) and maintaining specific types of cultural behaviour and practices (Thomas \& Znaniecki, 1918). The considerable migratory and rural influxes to Cayenne thus bring together in the same space groups with different cultures and diverse relationships with the environment and health, and being often 
characterised by strong relationships with the non-human, which flourish even in an unfavourable context. However, similarly to the life trajectory of the "Polish peasant" of Thomas and Znaniecki (1918) - oscillating between "conformism" with tradition and tendency towards change - we might suppose that the current transitional stage will give way either to the progressive loss of certain practices (Marc, 2007), or to the establishment of new ethnobotanical practices in the urban landscape, as noted by several authors (Baudry, 2015; Baudry et al., 2014; Ceuterick et al., 2008; Ellena et al., 2012; Ososki et al., 2007; Pellegrini \& Baudry, 2014; Tareau et al., 2017; van Andel \& Carvalheiro, 2013; van Andel \& Westers, 2010).

Whilst the appearance of towns is being changed by the ways its inhabitants use them, transforming the neighbourhood landscape by cultivating or protecting specific plant varieties, it is also of interest to examine another example of plant collection in Guiana today to understand the real situation of collection today: the case of the Ndjuka, major gatherers and users of wild plants.

Illustration 2 - Momordica charantia L. growing wild on a town fence at the entrance to Cayenne, on the Montabo road

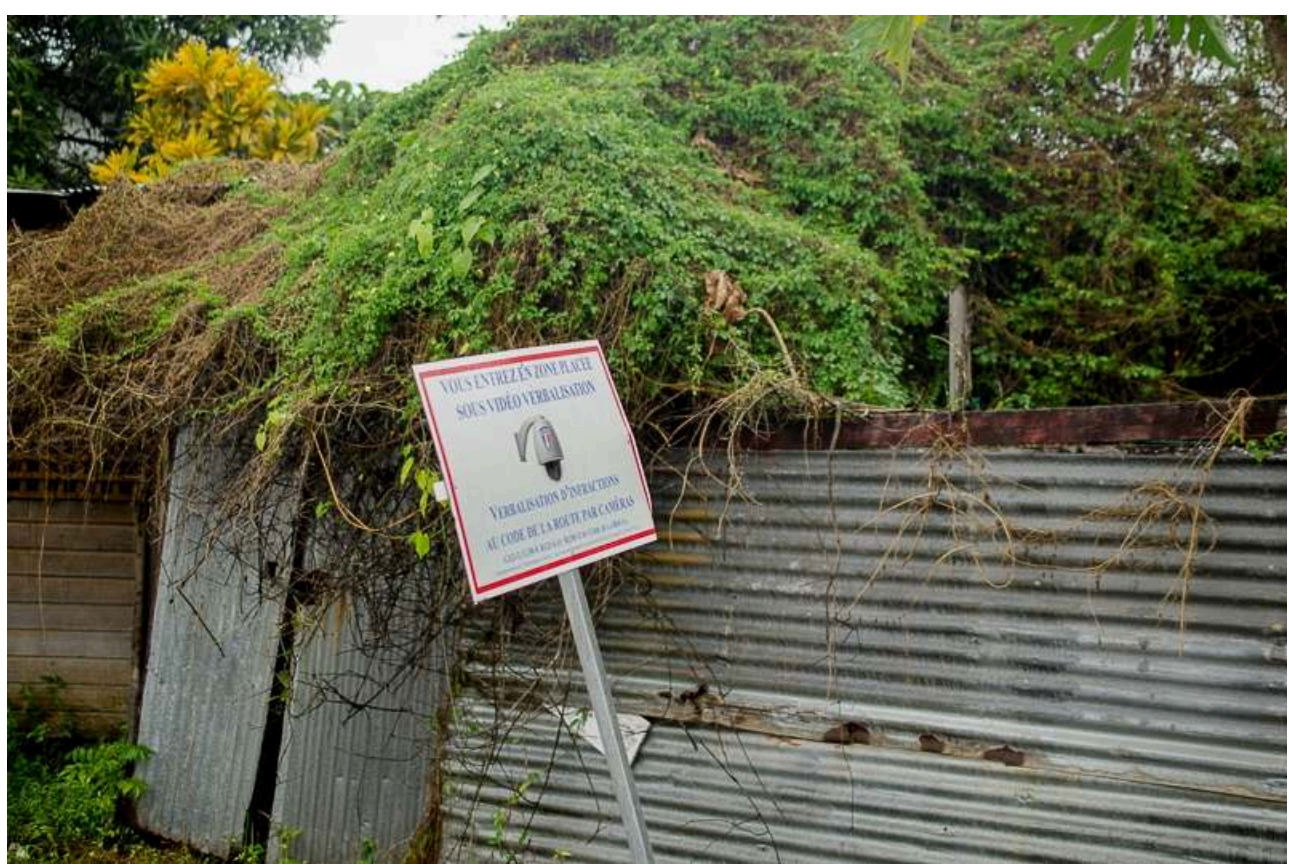

Author: M.-A. Tareau, May 2018

\section{An Afro-Amazon paradigm of collection: French Guiana's Maroon societies}

The Ndjuka are part of the Maroon population, called Businenge in Guiana, whose communities were originally runaway slaves from Dutch plantations in Suriname in the $17^{\text {th }}$ and $18^{\text {th }}$ centuries (Price \& Price, 2008). They quickly established themselves in unique and self-sufficient cultural groups, living mainly deep inside the forest (Moomou, 2002). Their total population today is estimated to number over 117,600 (Price, 2013a) distributed across the two neighbouring countries. There are four groups in French Guiana: the Saamaka, the Aluku, the Paamaka, and the Ndjuka. Thousands of 
the latter group, victims of ethnocide during the civil war in Suriname between 1986 and 1992, were forced to flee across the border into western French Guiana (Bourgarel, 1990). Most of today's inhabitants of the town of Saint-Laurent-du-Maroni are Businenge (Léobal, 2013). Several villages along the banks of the Maroni river and scattered across the open savannahs in Mana coastal municipality, where refugee camps were set up, are also home to a considerable Ndjuka population that continues to maintain strong ties to their original villages, which they visit regularly (Collomb \& Jolivet, 2008).

The ethnogenesis of Maroon groups, characterised by an escape from attacks by colonial militia, made them familiar with the edible and medicinal varieties essential for their survival in the rainforest. The isolation of the original communities deep in the forest (Price, 2013, 2010), African bio-cultural heritage (Carney \& Rosomoff, 2011; Fleury, 2015, 1991; Grimé, 1979; van Andel, 2016; van Andel et al., 2012a; Van Andel et al., 2014; Vossen et al., 2014) and above all numerous Amerindian inputs ${ }^{8}$ (Carney, 2003; Dupuy, 2007; Price \& Mintz, 2013; van Andel, 2016; van Andel et al., 2013) have helped shape a complex Ndjuka ethnomedicine (Sauvain et al., 1988; Vernon, 1992, 1993) which uses numerous wild species (Sauvain et al., 1988). The daily need for women to bathe in herbal concoctions 9 (Fleury, 1996; van Andel et al., 2008; van't Klooster et al., 2018) and for men to consume bita (blends of plants macerated in rum) as bitter tonic cups to "purify the blood" (Odonne et al., 2007; Sauvain et al., 1988; Tareau et al., 2017; van Andel et al., 2012a) are for the most part made possible by collecting plants. Lastly, plants used in winti ${ }^{10}$ medical-magic rituals are generally collected in the wild, in order to ensure greater therapeutic-spiritual (kaakiti) power. Indeed, ampuku, the forest spirit of African origin (Wooding, 1979) which symbolises nature untouched by humans (van Velzen \& van Wetering, 1988) and is the most invoked class of spirit (Fleury, 1991; van Andel et al., 2013), lives in wild plants which must therefore not be domesticated ${ }^{11}$ so as not to lose their sacred essence ${ }^{12}$, or for fear of bringing feared spirits too close to the domestic environment. Through the kaakiti that they obtain from the different preparations made from wild plants, Maroons become one with the forest, true Businenge ("Men of the Jungle"), which makes this plant collection-based therapy an inherent characteristic of the cultural identity of the Maroon population. This animist ontology as understood by P. Descola (2001) is therefore characterised by belief in a pantheon of non-human animate entities who inhabit the forest ${ }^{13}$, and the method used by L. Cabrera (Cabrera, 2003) to describe the Afro-Cuban forest from an emic perspective, could very appropriately be used to describe how the Ndjuka see the forest:

The Black [...] who goes deep inside the jungle is conscious of the direct contact he establishes with the forces of nature surrounding him, and that are the rulers of a domain that belongs to them. [...] "The jungle is sacred" because it is where divinities reside and live. Saints are in the jungle, rather than in heaven. (Cabrera, 2003)

S. Bahuchet (1997), in his comparison of African Pygmies with certain Amazon groups, showed that two of the main characteristics of tropical forest-dwelling populations is that they make extensive use of the wild plant resources they gather, and that "the untouched forest is the domain of the spirits". The symbolic representation frameworks of Ndjuka Maroons and their phyto-medicinal needs covered by wild varieties mean that they are significant gatherers "by culture". One of the sayings used in the community to express this close relationship with plant life in their surroundings is: "Mi no sabi fu 
wiri, den sabi fu mi!" ("I do not know plants, it is they who know me"). For all of these reasons, when the Ndjuka move into urban areas, they bring their collection practices with them to a certain extent (illustration 3). Informal and more or less organised networks for gathering and sending wild plants have also been set up to supply the needs of "neo-urbanites" and populations who have emigrated to Europe (Van Andel et al., 2007). Plants can be bought at the market. Lastly, on their trips to and fro between villages, rural populations regularly gather plants to supply their own needs and those of family members.

Illustration 3 - Businenge woman living in Cayenne, picking "maternity" plants in Rémire-Montjoly

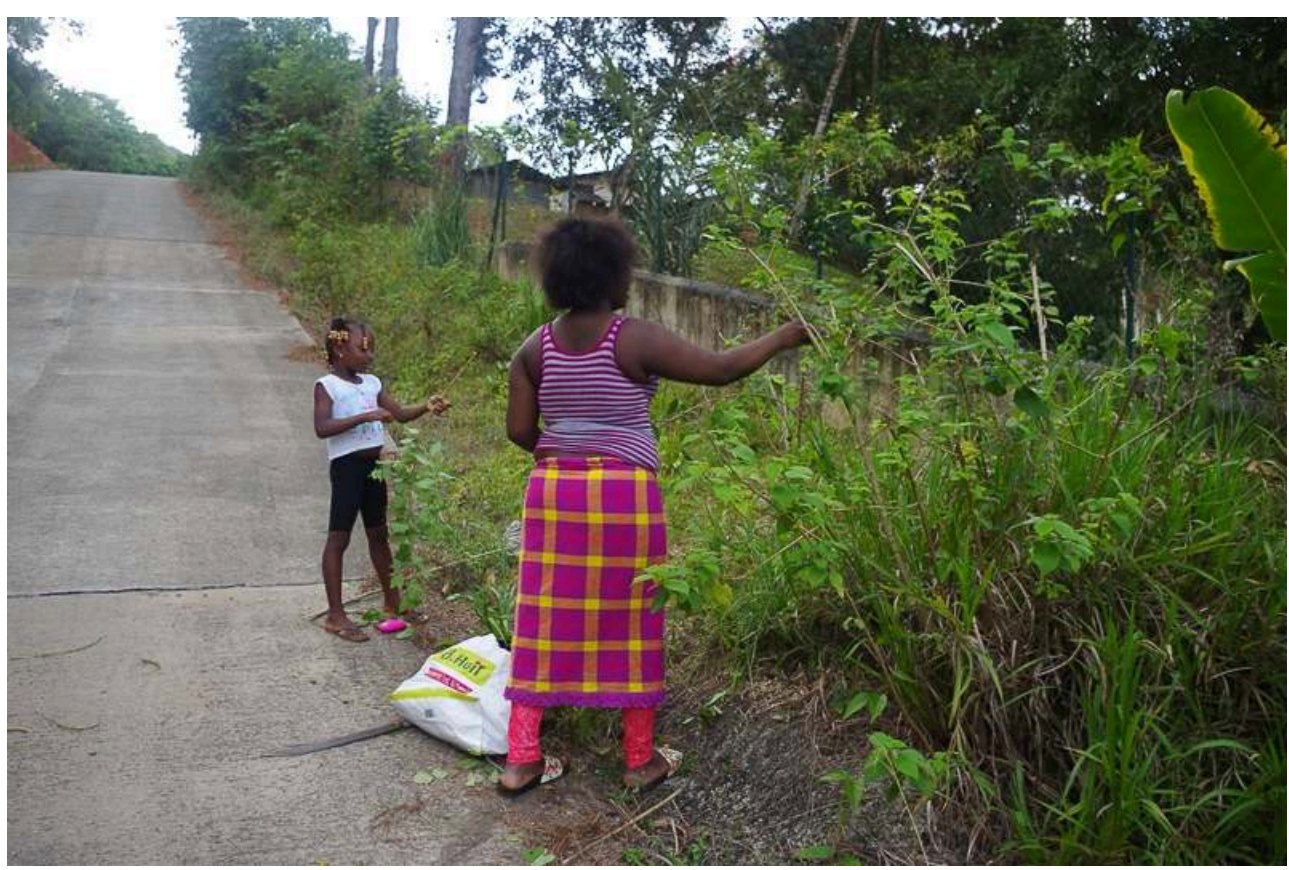

Author: M.-A. Tareau, April 2018.

\section{Gathering spaces: a cultural geography of gathered plants}

\section{Well-defined and distinct collection spaces: the "collection circles" in Ndjuka villages}

The omnipresence of plants in the daily practices of Ndjuka living in the Lower Maroni region brings with it structured gathering, organised according to criteria for use, gender and space. Villagers therefore make a distinction between three collection spaces (illustration 4), similar to the classic dwelling-garden-forest ethnographic model described by numerous anthropologists in the Amazon, amongst whom P. Descola ${ }^{14}$ (2004b) concerning the Achuar, and M. Lenaerts concerning the Asheninka (Lenaerts, $2006)^{15}$. This division of the social space into circles, each one with its inherent symbolic representations and specific uses, has also been described in sub-Saharan Africa (Bahuchet, 1997; Garine-Wichatitsy, 1997). Although subject of relevant analysis by B. Albert and F. M. Le Tourneau (2007), these spaces are used differently by the Ndjuka, as we shall see further on. However, the reticular collection spaces suggested by these 
authors are also relevant. In the Ndjuka case, circles are characterised not least by the different varieties collected in them, the uses made of them and by the gender of users ${ }^{16}$, revealed clearly in interviews which endorse the following breakdown:

\section{The domestic space}

The nearby circle surrounding the dwelling is for the osu deesi ("household remedies"), i.e. the space given over to the varieties used for domestic treatments and minor common ailments. This is an essentially female collection space (Voeks, 2007): this is where mothers come to find the specific plants they need to take care of their children - essentially small, semi-wild herbaceous plants. Gathering is therefore done ad hoc, according to needs. The Ndjuka consider that plants growing around dwellings can be picked freely by anyone who has need of them. This is sometimes a cause of perplexity for communities from different neighbourhoods, as the Ndjuka will pick plants that are around houses lived in by Amerindians, who nurture these plants carefully and consider them as something privately-owned ${ }^{17}$.

Illustration 4 - Concentric gathering spaces around a Ndjuka village

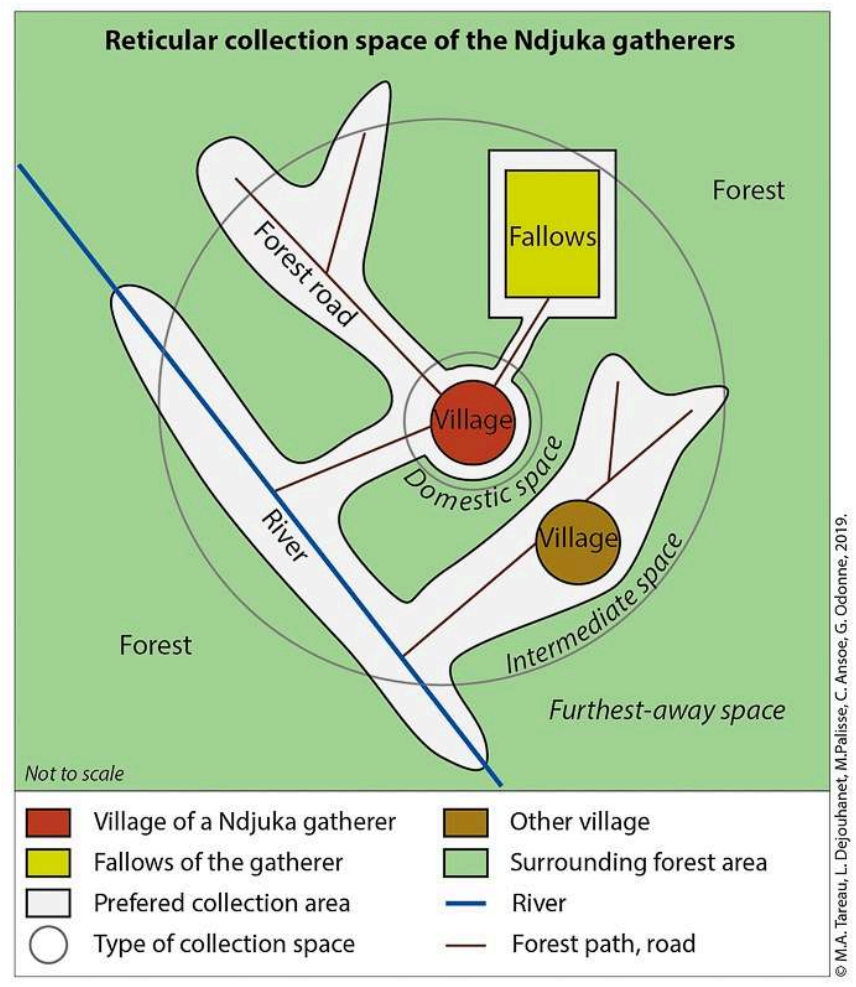

\section{The intermediate space}

Daily trips are made around the intermediate space to go to fallows or areas near the village. It therefore comprises fields, footpaths and wilderness, savannas and the secondary forest around them, river banks and roadside verges. This space can be called the uman sama deesi, i.e. the space for "women's remedies". This is mainly where the plants used for feminine hygiene or maternity are found, as Havinga (2006) also says in his study on medicinal plant collection by the Maroon population in Suriname. Even so, mixed collection also takes place in this circle: on their way to the slash-and- 
burn parcel (an essentially female space), women gather ruderal varieties ${ }^{18}$ growing along the paths, or self-sown plants growing in the fields; but when they are unable to move about much (because they are pregnant or sick), or when they cannot go in search of plants themselves because they are menstruating ${ }^{19}$, the men will go and find the plants that the women need for bathing. When men set off along the paths to go hunting or to visit other villages, they also regularly gather plants for their wives. Here, mobility and trips are occasions and even reasons for collection, which makes this intermediate circle into a reticular space which runs along paths, roads and around bodies of water which form the axes of access to the resource, similar to the way described for the Yanomami (Albert \& Le Tourneau, 2007).

This intermediate space ${ }^{20}$ is unquestionably the most important gathering space in Ndjuka villages. According to Havinga, $85 \%$ of the wild plants collected by the Maroon population in Suriname are gathered from inhabited areas and secondary forests (Havinga, 2006). As has been observed among the Gimbe and Duupa in Cameroon (Garine-Wichatitsky, 1997), the plants gathered from this circle are considered the best, insofar as they are the "happy medium" between a potentially contaminated domestic circle (in this case, specifically by menstrual blood) and the deep forest where oftenfeared "spirits" live. Favourite plants are therefore the ruderal shrubs that grow along paths, and the self-sown plants ${ }^{21}$ that grow in fields, which some authors consider to be the midline varieties on the wild-to-domesticated continuum, a sort of "domesticated wild" plant (Harlan \& Technique, 1987; Haudricourt \& Hédin, 1987). These plants are certainly wild, but they are spread during hoeing or clearing, and even encouraged (Harlan \& Technique, 1987) or re-planted near dwellings ${ }^{22}$.

\section{The furthest-away gathering space}

The distal circle is where deesi fu mindii busi ("deep wood remedies") are found. This is a male space, the heart of the rainforest being the domain of men where they go mainly to hunt (illustration 5) and to harvest the edible fruit of palms. They collect wild lianas or bark from large ligneous species to prepare their bita ${ }^{23}$, specific types of bark used by women for personal hygiene (ketee), and plants for winti $i^{24}$, a large number of which owe their magical efficacy to the fact that they come from the "deep woods" (van Andel et al., 2013). Some forest gatherers are "professional", i.e. they sell the varieties they pick in the forest in order to supplement what they earn from hunting: the species picked are sold on to vendors, or sometimes door-to-door. Bar managers in towns also sometimes place their orders directly with hunters for the ingredients they need to prepare their bita.

Illustration 5 - A Ndjuka hunter returning from the hunt with medicinal plants gathered from mature forest. 


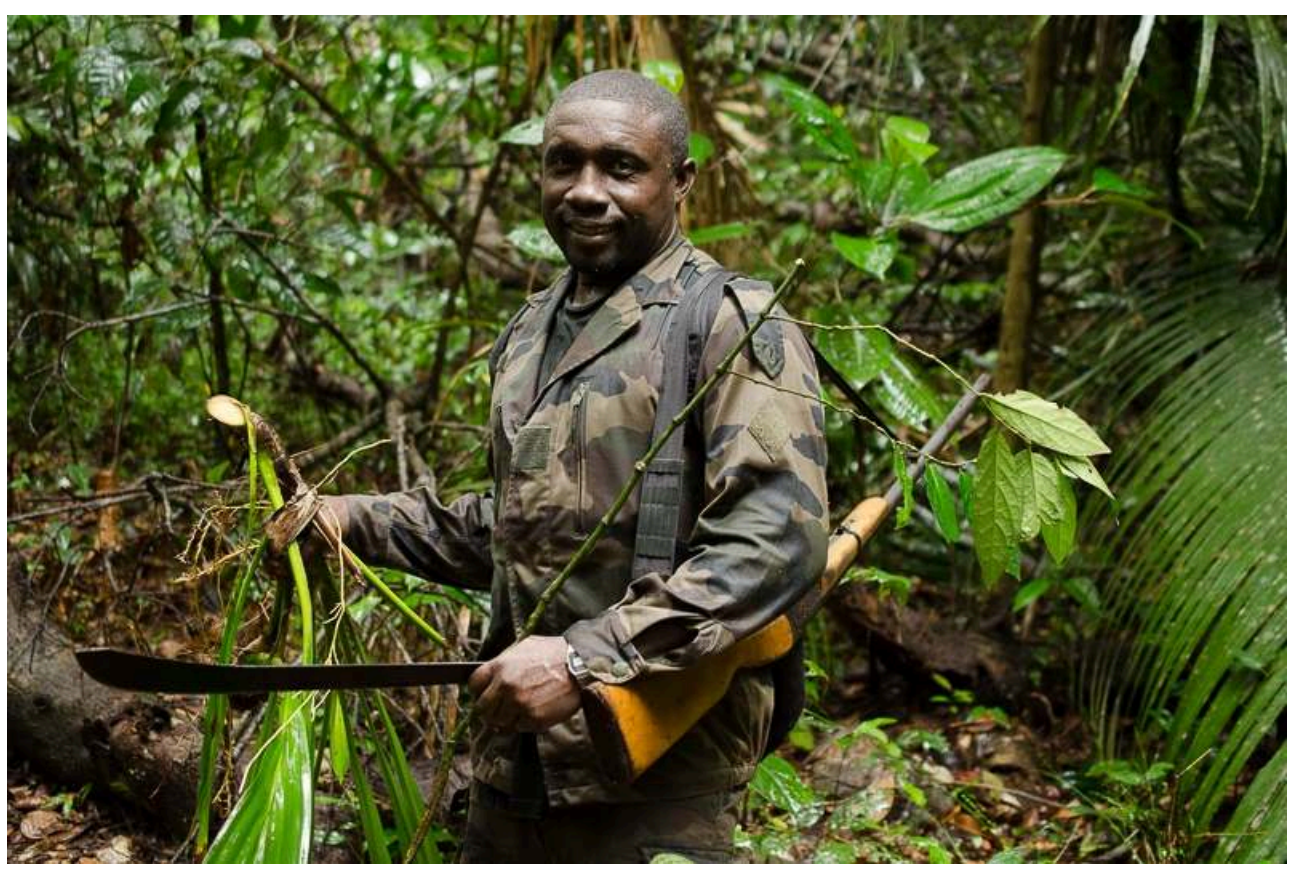

Author: M. Rapinski, November 2017.

\section{Adapting gathering "circles" to the urban environment, the Cayenne example}

The "gathering circles" described for the Ndjuka still seem to be operating in towns, but with some adjustments (illustration 6). We can in effect make a distinction between the domestic space and the intermediate space in terms of distance from home: the former covers the immediate surroundings and the neighbourhood area within walking distance from home, and the latter covers longer distances for which vehicular transport is necessary. So whilst the domestic space invariably covers the areas around the home and spreads out into the neighbourhood, the intermediate space is more an archipelago of spots where people know that plants can be found and picked: ruderal herbaceous varieties or cultivated plants which spread beyond garden enclosures in towns. The border between the two spaces becomes more blurred, however, if we consider the varieties collected in both "circles", because they are the same ones. The access routes to new suburban neighbourhoods and the verges along roads in Cayenne are also used for collection activities, echoing the reticular space of fallows and along the paths in the rural environment, and they also make up the intermediate gathering circle, the de facto "living space" of inhabitants (Frémont, 1999) ${ }^{25}$.

But town dwellers also go to look for medicinal plants in the woodlands and other suburban protected natural areas, the features of which make them the third gathering circle. In Cayenne, the wooded knolls scattered across the urban space are important collection spots (Tareau et al., to be published). The "historical" populations (Brazilian, Businenge, Creole) make good use of these woodlands because they know the local natural environment well, and the resources they can obtain from it. However, these spaces are also used by immigrants, particularly Haitians, who cultivate a lot of gardens there (Palisse, 2016). This last circle is the furthest away: urban woodlands that form separate and scattered pockets. This fragmentation of space in the city (illustration 6) 
gives rise to archipelagos of "urban pockets" (Saint-Laurent, 2000), the multi-polarity of which is moreover favoured by the longer distances covered in trips around the urban area (Hubert \& Delisle, 2010).

Illustration 6 - Organisation of gathering space in Cayenne.

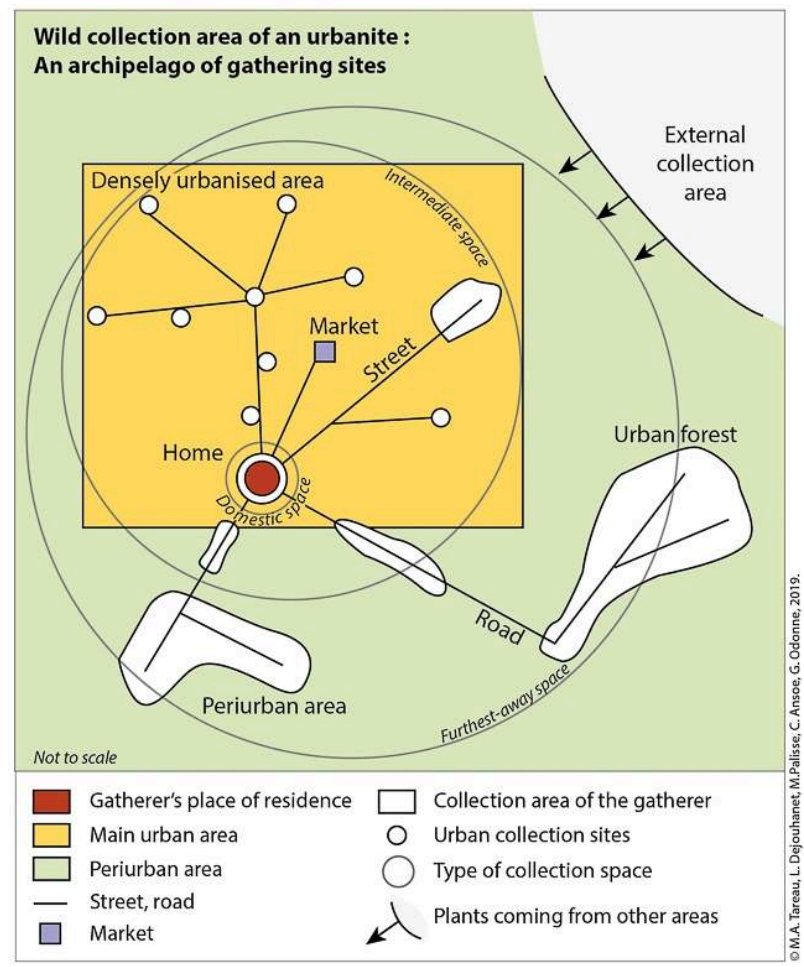

\section{Characterising the collection of medicinal plants}

\section{Heterogeneity as a multi-factorial determinant of collection}

Beyond this spatial organisation, the diversity of collection situations observed on the ground leads us to think that the idea of "heterogeneity" (Abreu et al., 2015; Ladio \& Albuquerque, 2014) can provide a means of interpretation that facilitates understanding these collection processes. The heterogeneity of collection practices is found at the convergence point of three areas of heterogeneity, which unquestionably complement each other (illustration 7), acting as three decisive contextual ingredients:

- Cultural heterogeneity, due to the presence of several groups of different origins sharing the same space. In a multicultural space like Cayenne, each group chooses its collection spaces and the varieties it will collect, linked to the uses of that particular group. However, these practices are not devoid of a degree of permeability between groups.

- Socio-economic differences also have a significant bearing on collection practices, since different living standards mean different access to biomedical healthcare (Valmy et al., 2015), in turn leading to different herbal remedy needs. In addition, unequal access to means of transport causes inequitable distribution of resources (Cerqueira, 2017). And lastly, legal status is also an explanatory factor insofar as "illegals" gather from a smaller area, as they tend not to stray far from where they live for fear of being arrested by the police. 
- Lastly, ecological diversity is also a factor that must be taken into account. The diversity of biotopes to which inhabitants have access encourages the appearance of different types of gathering and increases the number of varieties that may potentially be picked. Varied and protected environments thus favour more diversified gathering practices. By contrast, the urban environment (towns and cities must effectively be considered as full-blown ecological systems with their own climate, heterogeneity and biodiversity) (Arnould et al., 2011) limits individuals to more exploratory and fragmented practices, where they need to look for plants in less-defined areas, on wasteland or in small interstitial areas.

Illustration 7 - A system of heterogeneities to explain gathering practices

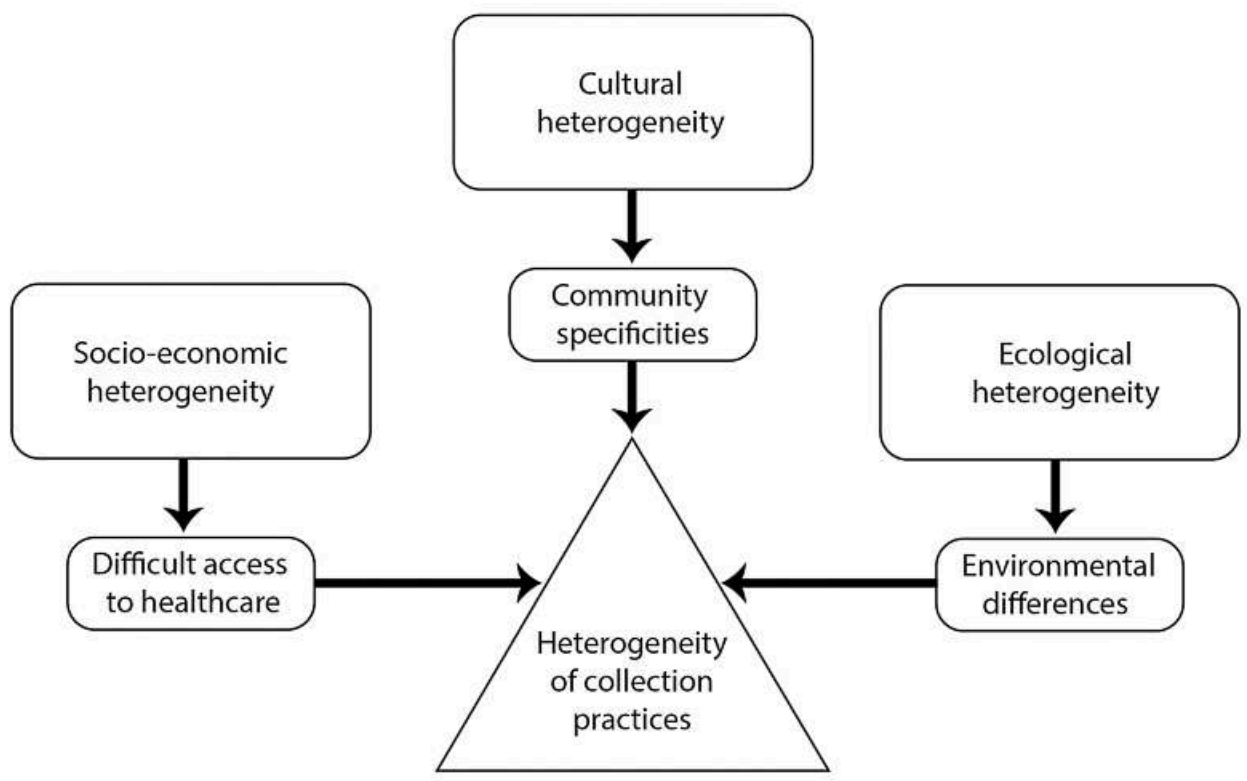

This concept of heterogeneity thus enables us better to understand the different gathering practices observed in different spaces. Although ecological diversity may appear to be of less importance in the urban environment, the socio-economic conditions and cultural heterogeneity of the communities living in Cayenne make for a more diverse mosaic of practices than we find in the Lower Maroni region. Not only Businenge populations have "relocated" some of the cultural practices used in villagebased gathering into the urban context (Ladio \& Albuquerque, 2014). The same is true for other groups (Haitians, Creoles, etc.), and this de facto causes collection practices to overlap in urban spaces. Here, the heterogeneity of practices is primarily determined by the variety of social and cultural situations.

\section{The aims of collection: theoretical approach}

Lastly, analysing why gatherers gather would also appear to be relevant for drawing up an explanatory diagram of medicinal plant collection (illustration 8). At the first level of explanation, we can differentiate between commercial collection and domestic collection, which by their very nature have different purposes.

As regards domestic collection, three main aims can be seen which are linked to the three areas of heterogeneity described above. First, people who have limited access to biomedical care for financial reasons ("medicines are expensive in the pharmacy"), 
administrative reasons (illegal immigrants) or geographical reasons (remote sites) are more likely to collect medicinal plants to meet their primary care needs. People who already grow a number of medicinal varieties will sometimes go out and pick the ones they don't have for preparing a home-made remedy (or get them from the market); this is what we term complementary therapeutic collection. In this instance, there is complementarity between plants cultivated in the garden and wild plants growing outside it. Lastly, certain specific cultural needs are important factors in collection. As we have seen with the Ndjuka, booko fu ketee ${ }^{26}$ is such a widespread practice that it pushes women who live in towns to go out collecting. Among the Haitian community, the preparation of bottles of asosi also leads town dwellers to go in search of, nurture and collect Momordica charantia leaves.

As regards commercial collection, it is primarily motivated by profit (Dejouhanet, 2014). Selling medicinal plants stands out as specific to the urban environment, where it is done to meet a demand. In the rural environment where this resource is plentiful, monetising it is a largely redundant exercise. There are very few outfits that process medicinal plants, and the networks that sell to these small businesses are few in number and low-profile. Vendors may process the raw materials themselves to increase their added value.

These aim ${ }^{27}$ reveal three types of collection which may be practised by individuals and vendors alike:

- Targeted collection, deliberate searches with a specific goal. Gatherers go out in search of a plant that they need to prepare a specific remedy, or in response to a purchase order by a third party. This type of collection is essentially made possible thanks to the mental mapping of medicinal plant locations done by individuals. In the countryside and in the town alike, the location of plants that may potentially be required is routinely spotted and remembered by inhabitants.

- Ad hoc collection, non-deliberate. The plants picked are plants that people "come across" in the course of their trips to and fro, or on particular occasions (working in the fields, going hunting, etc.) and are picked ad hoc (and therefore unplanned).

- Complementary collection, which is multifunctional collection; it is deliberate (people go out intentionally to collect plants) but not specific (they do not yet know which plants they will find). Typically, this type of collection is done during agricultural work, hunting forays, or when harvesting palm fruits. This collection can be domestic, when the plants picked are for the gatherer's family members, or commercial, when the gatherer uses it to earn additional income. 
Illustration 8 - Explanatory diagram showing medicinal plant collection, based on collection in Cayenne and by the Ndjuka population in the Lower Maroni

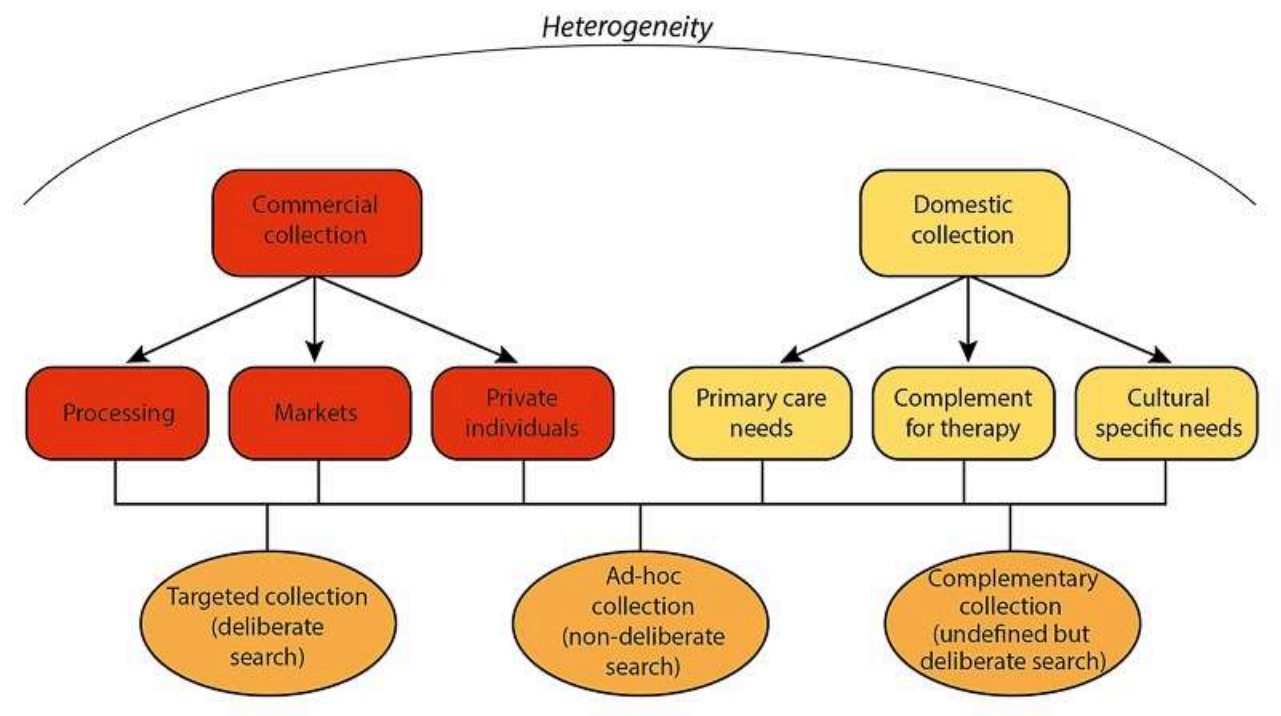

\section{Conclusion}

The multicultural context in French Guiana and rapid population growth facilitate a very rich analysis of social systems undergoing transformation. Plant collection practices, often considered a vestige of development levels belonging to the past, are still thriving in French Guiana: they happen frequently, they travel with populations, and they adapt to new environments. We analyse them here from several conceptual perspectives.

One of them is heterogeneity, which enables us to understand the abundance of practices. The socio-cultural features of populations and the ecological features of the environment give rise to a great diversity of collection practices, which are also dictated by the economic context in which they take place: practices result from specific combinations of the three areas of heterogeneity described above.

Understanding the spatial distribution of practices is the second level of analysis: three zones - the nearby/domestic, the intermediate and the distant/suburban - have been able to be defined based on closeness to dwelling place, habitual routes, and associated spiritual representations. The plants gathered in these three zones differ both from the botanical point of view and in terms of therapeutic indications, because their properties are closely linked to these cultural representations. These theoretical "circles", spreading outwards from the gatherer's dwelling, partially survive the transition from the village environment to the urban one, albeit with some adjustments. The balance between the three levels seems to shift in favour of an enormous reticular space in the intermediate zone, the geometry of which varies according to the mobility means of gatherers.

And lastly, the purposes underlying different collection practices provide another view of them. Collections can be divided into targeted collection, ad hoc collection and complementary collection, depending on whether the activity is planned or not and whether specific plants are being sought. The dichotomy between commercial collection and domestic collection is not yet that significant in Guyana, but changing 
lifestyles and population movements could increase the need for these plants among populations no longer able to go and gather them for themselves. This might lead to the development of new commercial networks, as is the case today in neighbouring country Suriname.

\section{BIBLIOGRAPHY}

Abreu D. B. de O., Santoro F. R., Albuquerque U. P. de, Ladio A. H., Medeiros P. M. de, 2015. Medicinal plant knowledge in a context of cultural pluralism: A case study in Northeastern Brazil. Journal of Ethnopharmacology, vol. 175, n 1, p. 124-130.

Albert B., Le Tourneau F.-M., 2007. Ethnogeography and resource use among the Yanomami: Toward a model of "reticular space." Current Anthropology, vol. 48, n 4, p. 584-592.

Arnould P., Cieslak C., 2004. Presentation of natural objects in Paris and Warsaw: remarkable trees of two periurban woods. Natures Sciences Sociétés, vol. 12, n² 2, p. 157-171.

Arnould P., Le Lay Y.-F., Dodane C., Méliani I., 2011. La nature en ville : l'improbable biodiversité. Géographie Économie Société, vol. 13, n 1, p. 45-68.

Auburtin R., 2007. La production du logement en Guyane: contraintes réglementaires et contrepratiques populaires. In Man Lam Fouck S. (ed.), Comprendre la Guyane d'aujourd'hui. Un département français dans la région des Guyanes. Matoury, Ibis Rouge.

Auburtin R., 2006. De Cayenne à Kourou, singularité des villes françaises de Guyane : entre habitat d'ordonnance et habitat auto-construit, la question du logement. Thèse de Doctorat, Paris 3, 484 p. Bahuchet S., 1997. Un style de vie en voie de mutation. Considérations sur les peuples des forêts denses humides. Civilisations. Revue internationale d'anthropologie et de sciences humaines, vol. 44, $\mathrm{n}^{\circ} 1$, p. 16-31.

Baudry S., 2015. Gestion environnementale de la voie publique par les citoyens : mise en relation des discours officiels et des pratiques quotidiennes locales à Paris et New York City. In Beringuier P., Frédérique Blot F., Desailly B., Saqalli M. (dir.), Environnement, politiques publiques et pratiques locales. Paris, L'Harmattan, 2015, p. 50-68.

Baudry S., Scapino J., Rémy E., 2014. L'espace public à l'épreuve des jardins collectifs à New York et Paris. Géocarrefour : Revue de géographie de Lyon, vol. 89, n 1, p. 41-51.

Bourdeau-Lepage L., Vidal R., 2012. Nature urbaine en débat : à quelle demande sociale répond la nature en ville? Demeter Journal, vol. 13, n 1, p. 195-210.

Bourgarel S., 1990. Les réfugiés surinamiens en Guyane. Etudes Créoles, vol. 13, n² 2, p. 7-29.

Burgess E.W., 1929. Urban areas. Chicago: An experiment in social science research, vol. 12, $\mathrm{n}^{\circ} 1$, p. 113-138.

Bussmann R.W., Sharon D., 2009. Markets, Healers, Vendors, Collectors: The Sustainability of Medicinal Plant Use in Northern Peru. Mountain Research and Development, vol. 29, n 1, p. 128-134.

Cabrera L., 2003. La Forêt et les Dieux. Religions afro-cubaines et médecine sacrée à Cuba. Paris, Jean Michel Place, $603 \mathrm{p}$. 
Carde E., 2006. Les discriminations selon l'origine dans l'accès aux soins. Etude en France métropolitaine et en Guyane française. Thèse de Doctorat, Université Paris Sud - Paris XI, 541 p.

Carney J., Rosomoff R.N., 2011. In the shadow of slavery: Africa's botanical legacy in the Atlantic world. USA, University of California Press, 296 p.

Carney J.A., 2003. African traditional plant knowledge in the circum-Caribbean region. Journal of Ethnobiology, vol. 23, n², p. 167-186.

Cerqueira E.V., 2017. Les inégalités d'accès aux ressources urbaines dans les franges périphériques de Belo Horizonte (Brésil) : quelles évolutions ? EchoGéo [En ligne], n 39. http:// journals.openedition.org/echogeo/14856

Ceuterick M., Vandebroek I., Torry B., Pieroni A., 2008. Cross-cultural adaptation in urban ethnobotany: The Colombian folk pharmacopoeia in London. Journal of Ethnopharmacoly, vol. 120, $\mathrm{n}^{\circ}$ 3, p. 342-359.

Clastres P., 1972. Chronique des Indiens Guayaki. Ce que savent les Aché, chasseurs-nomades du Paraguay. Paris, Plon, 320 p.

Clément G., 2014 [2004 : $1^{\text {ère }}$ ed.]. Manifeste du Tiers paysage. Paris, Sens \& Tonka, 48 p.

Collomb G., Jolivet M.-J., 2008. Histoires, identités et logiques ethniques: Amérindiens, Créoles et NoirsMarrons en Guyane. Paris, Éditions du CTHS, 221 p.

Dejouhanet L., 2014. Secteur informel et réseaux de commercialisation des plantes médicinales au Kerala (Inde). Économie Rurale [En ligne], n³43, p. 53-70. https://journals.openedition.org/ economierurale/4447

Descola P., 2004a. Le sauvage et le domestique. Communications, vol. 76, $\mathrm{n}^{\circ}$ 1, p. 17-39.

Descola P., 2004b. La Nature domestique : Symbolisme et praxis dans l'écologie des Achuar. Paris, Les Editions de la MSH, $234 \mathrm{p}$.

Descola P., 2001. Par-delà la nature et la culture. Le Débat, vol. 114, n 3, p. 86-101.

Descola P., 1993. Les Affinités sélectives : Alliance, guerre et prédation dans l'ensemble jivaro. L'Homme, vol. 33, nº 12, p. 171-190.

Dupuy F., 2007. Dynamiques interethniques dans le haut Maroni. In Léglise I., Migge B., (ed.), Pratiques et Représentations Linguistiques en Guyane. Regards Croisés. Paris, IRD Éditions, p. 107-117.

Ellena R., Quave C.L., Pieroni A., 2012. Comparative Medical Ethnobotany of the Senegalese Community Living in Turin (Northwestern Italy) and in Adeane (Southern Senegal). EvidenceBased Complementary and Alternative Medicine [En Ligne], vol. 2012. http://dx.doi.org/ $10.1155 / 2012 / 604363$

Fleury M., 2015. Plantes médicinales chez les Aluku (Boni) du Haut-Maroni : origine, symbolique et usages. In Sociétés marrones des Amériques. Mémoires, patrimoines, identités et histoire du $17^{e ̀ m e}$ au $20^{\mathrm{ème}}$ siècles. Matoury, Ibis Rouge.

Fleury M., 1996. Végétaux utilisés pour l'hygiène intime des femmes Aluku en Guyane française : interprétation culturelle et intérêt pharmacologique. In Schröder E., Balansard G., Cabalion P., Fleurentin J., Mazars G., Ethnopharmacologie. Sources, méthodes, objectifs. Paris, Société française d'Ethnopharmacologie - Editions de l'ORSTOM, p. 178-186.

Fleury M., 1991. Busi-Nenge, les hommes-forêt : Essai d'ethnobotanique chez les Aluku (Boni) en Guyane française. Thèse de doctorat, Université Paris 6, $392 \mathrm{p}$.

Frémont A., 1999. La région, espace vécu. Paris, Flammarion, 288 p. 
Gardel A., 2001. Les paysages urbains de l'île de Cayenne, Guyane Française. Mappemonde, vol. 63, $\mathrm{n}^{\circ} 3$, p. 16-21.

Garine-Wichatitsky É., 1997. Sauvage ou domestique ? Remarques sur l'inventaire des plantes à brèdes chez les Gimbe et les Duupa du Nord-Cameroun In Barreteau D., Dognin R., Von Graffenried C., Homme Milieu Végétal Dans Bassin Lac Tchad, Paris, ORSTOM Editions, p. 311-326.

Ghimire S.K., Doyle M., Yildiz A., 2004. Heterogeneity in ethnoecological knowledge and management of medicinal plants in the Himalayas of Nepal: implications for conservation . Ecology and Society, [En Ligne], Volume 9, n 3. http://www.ecologyandsociety.org/vol9/iss3/art6/

Godinho I., 1984. Les définitions d'« adventice » et de " mauvaise herbe », Weed Research, vol. 2, $\mathrm{n}^{\circ} 24$, p. $121-125$.

Gorgeon C., 1985. Immigration clandestine et bidonvilles en Guyane, les Haïtiens à Cayenne. Revue européenne des migrations internationales. vol. 1, nº 1, p. 143-158.

Grafmeyer Y., Joseph I., 1984, L'École de Chicago. Naissance de l'écologie urbaine. Paris, Aubier, 378 p. Grimé W.E., 1979, Ethno-botany of the Black Americans. USA, References Publications, 237 p.

Harlan J.R., et Technique A. de C.C., 1987. Les plantes cultivées et l'homme. Paris, Payot, 414 p.

Haudricourt A.-G., Hédin L., 1987. L’Homme et les plantes cultivées. Paris, Gallimard, 290 p.

Havinga R.M., 2006. Harvest of Medicinal Plants in Surinamese Maroon Society: Implications for sustainability. Mémoire de Maîtrise, Université d'Utrecht, 59 p.

Hubert J.-P., Delisle F., 2010. L'allongement des déplacements quotidiens contribue à l'émergence d'espaces urbains multipolaires, tandis que la mobilité baisse au centre des grandes agglomérations. La Revue du CGDD, vol. 3, n 2, p. 49-64.

Hurpeau B., 2012. Panorama de la population immigrée en Guyane. France, INSEE Antilles-Guyane, $21 \mathrm{p}$.

INSEE, 2014. Recensement de la population en Guyane - 252338 habitants au 1er janvier 2014 [En Ligne]. https://www.insee.fr/fr/statistiques/2540209

Jolivet M.-J., 1982. La question créole. Essai de sociologie sur la Guyane française. Paris, Editions de l'ORSTOM, $495 \mathrm{p}$.

Ladio A.H., Albuquerque U.P., 2014. The concept of hybridization and its contribution to urban ethnobiology. Ethnobiology and Conservation, vol. 3, p. 1-9.

Landy F., Belaidi N., Sada K.-H.G., 2017. Les espaces protégés urbains, vecteurs de justice ou d'injustice pour les populations autochtones? Les cas de Xochimilco et des parcs nationaux de Mumbai et du Cap. Justice spatiale/ Spatial Justice [En ligne], $n^{\circ}$ 11. http://www.jssj.org/article/lesespaces-proteges-urbains-vecteurs-de-justice-ou-dinjustice-pour-les-populations-autochtonesles-cas-de-xochimilco-et-des-parcs-nationaux-de-mumbai-et-du-cap/

Lenaerts M., 2006. Ontologie animique, ethnosciences et universalisme cognitif. Le regard ashéninka. L'Homme. Revue française d'anthropologie, vol. 179, n 33, p. 113-139.

Léobal C., 2013. Saint-Laurent du Maroni : une porte sur le fleuve. Matoury, Ibis Rouge éditions, 216 p. Marc J.-V., 2007. Le Végétal dans les espaces urbains et périurbains des petites antilles : Le cas de Fort-De-France. Thèse de Doctorat, Université des Antilles et de la Guyane, 337 p.

Moomou J., 2002. Le monde des Marrons du Maroni en Guyane (1772-1860). La naissance d'un peuple : les Boni. Matoury, Ibis Rouge Editions, 222 p. 
Nguenang G.M., Fedoung E.F., Nkongmeneck B.A., 2010. Importance des forêts secondaires pour la collecte des plantes utiles chez les Badjoué de l'Est Cameroun. Tropicultura, vol. 28, $\mathrm{n}^{\circ} 4$, p. 238-245.

Odonne G., Bourdy G., Beauchêne J., Houël E., Stien D., Chevolot L., Deharo E., 2007. From Toniccups to Bitter-cups: Kwasi bita beker from Suriname: Determination, past and present use of an ancient galenic artefact. Journal of Ethnopharmacology, vol. 110, $\mathrm{n}^{\circ}$ 2, p. 318-322.

Ososki A.L., Balick M.J., Daly, D.C., 2007. Medicinal plants and cultural variation across Dominican rural, urban, and transnational landscapes. In Pieroni A., Vandebroek I., Traveling Cultures and Plants: The Ethnobiology and Ethnopharmacy of Migrations. USA, Berghahn Books.

Palisse M., 2016. Les pratiques agricoles des migrants haïtiens en Guyane : entre insertion et stigmatisation. In Mobilités, ethnicités, diversité culturelle : La Guyane entre Suriname et Brésil. Matoury, Ibis rouge Editions.

Palisse M., 2013. Libres de savane. Pratiques et imaginaires autour des savanes de Guyane. Rapport de recherche, Université des Antilles-Guyane, $62 \mathrm{p}$.

Park R.E., Burgess, E.W., McKenzie, R.D., 1984. The city. USA, University of Chicago Press, 250 p.

Pellegrini P., Baudry S., 2014. Streets as new places to bring together both humans and plants: examples from Paris and Montpellier (France). Social \& Cultural Geography, Volume 15, $\mathrm{n}^{\circ} 8$, p. 871-900.

Piantoni F., 2011. Migrants en Guyane. Arles, Actes Sud. Editions, 176 p.

Price R., 2013a. Les Premiers Temps : la conception de l'histoire des Marrons Saamaka. Paris, Vents d'ailleurs, $304 \mathrm{p}$.

Price R., 2013b. « The Maroon Population Explosion: Suriname and Guyane ». New West Indian Guide/Nieuwe West-Indische Gids. Volume 87, n³, p. 323-327.

Price R., Mintz S.W., 2013. The birth of African-American culture. USA, Beacon Press, 144 p.

Price R., 2010. Voyage avec Tooy. Histoire, mémoire, imaginaire des Amériques Noires. Paris, Vents d'ailleurs, $520 \mathrm{p}$.

Price R., Price S., 2008, Les Marrons. Paris, Vents d'ailleurs, 128 p.

Romanovski Z., Piantoni F., 2009. Les stratégies d'accès au logement des Haïtiens dans l'agglomération de Cayenne comme facteurs de restructuration urbaine. L'Espace Politique. Revue en ligne de géographie politique et de géopolitique [En Ligne], $\mathrm{n}^{\circ} 3 \mathrm{http}$ //journals.openedition.org/ espacepolitique/1009; DOI : 10.4000/espacepolitique.1009

Roulleau-Berger L., Lu S., 2003. Les provinciaux à Shanghaï : Formes d'inscriptions urbaines et économiques des migrants dans la ville. Les Annales de la Recherche Urbaine, vol. 93, n 1, p. 48-56.

Saint-Laurent D., 2000. Approches biogéographiques de la nature en ville : parcs, espaces verts et friches. Cahiers de géographie du Québec, vol. 122-44, p. 147-166.

Sauvain M., Vernon D., Fleury M., Jamet P., Daniel R., 1988. Système de santé moderne et pratiques traditionnelles de santé chez les Noirs Marrons de Guyane et du Surinam : rapport d'activité. Paris, ORSTOM Editions, 83 p.

Sukopp H., Hejny S., 1990. Plants and plant communities in urban environments. The Netherlands, SPB Academic Publishing, $282 \mathrm{p}$.

Tareau M.A., Palisse M., Odonne G., 2017. As vivid as a weed... Medicinal and cosmetic plant uses amongst the urban youth in French Guiana. Journal of Ethnopharmacology, vol. 203, nº 1, p. 200-213. 
Tareau M.A., Odonne G., Fozzani J., Palisse M., à paraître. Pratiques de cueillette urbaine des plantes médicinales dans l'île de Cayenne. In Roger D., Guibert J-S., Habiter la ville ou la fabrique de la cité (vol 2). Rennes, Presses Universitaires de Rennes.

Thomas W.I., Znanieck, F., 1918. The Polish peasant in Europe and America: Monograph of an immigrant group. USA, University of Chicago Press, $317 \mathrm{p}$.

Valadeau C., 2016. Agir en secret : un regard sur la circulation des usages associés aux souchets des jardins, aux fougères des sous-bois et aux caladions des berges chez les Yanesha (Haute Amazonie péruvienne). Bulletin de l'Institut français d'études andines, vol. 45, n 1, p. 173-192.

Valmy L., Gontier, B., Parriault, M.C., Van Melle, A., Pavlovsky, T., Basurko, C., Grenier, C., Douine, M., Adenis, A., Nacher, M., 2015. Prevalence and predictive factors for renouncing medical care in poor populations of Cayenne, French Guiana. BMC health services research, vol. 16, $\mathrm{n}^{\circ} 1$, p. 34-45.

van Andel T., 2016. The Reinvention of Household Medicine by Enslaved Africans in Suriname. Social History of Medicine, vol. 29, $\mathrm{n}^{\circ}$ 4, p. 676-694.

van Andel T., Behari-Ramdas J., Havinga R., Groenendijk S., 2007. The medicinal plant trade in Suriname. Ethnobotany Research and Applications, vol. 5, $\mathrm{n}^{\circ} 1, \mathrm{p}$. 351-372.

van Andel T., Carvalheiro L.G., 2013. Why Urban Citizens in Developing Countries Use Traditional Medicines: The Case of Suriname. Evidence-Based Complementary and Alternative Medicine [En ligne], $\mathrm{n}^{\circ}$ 2013. http://dx.doi.org/10.1155/2013/687197

van Andel T., de Korte S., Koopmans D., Behari-Ramdas J., Ruysschaert S., 2008. Dry sex in Suriname. Journal of Ethnopharmacology, vol. 116, n 1, p. 84-88.

van Andel T., Mitchell S., Volpato G., Vandebroek I., 2012. In search of the perfect aphrodisiac: parallel use of bitter tonics in West Africa and the Caribbean. Journal of Ethnopharmacology, vol. $143, \mathrm{n}^{\circ} 3$, p. 840-850.

van Andel T., Ruysschaert S., Putte K.V. de, Groenendijk S., 2013. « What makes a plant magical? Symbolism and sacred herbs in Afro-Surinamese winti rituals » in African ethnobotany in the Americas. USA, Springer, 247-284.

van Andel T., Westers P., 2010. Why Surinamese migrants in the Netherlands continue to use medicinal herbs from their home country. Journal of Ethnopharmacoly, vol. 127, n 3, p. 694-701.

van Andel T.R., van't Klooster C.I., Quiroz D., Towns A.M., Ruysschaert S., van den Berg M., 2014. Local plant names reveal that enslaved Africans recognized substantial parts of the New World flora. Proceedings of the National Academy of Sciences, vol. 111-50, p. 346-353.

van Velzen H.U.E.T., van Wetering W., 1988. The Great Father and the Danger: religious cults, material forces, and collective fantasies in the world of the Surinamese Maroons. The Netherlands, Foris Publications, $88 \mathrm{p}$.

van't Klooster C.I., Haabo V., Ruysschaert S., Vossen T., van Andel T.R., 2018. Herbal bathing: an analysis of variation in plant use among Saramaccan and Aucan Maroons in Suriname. Journal of Ethnobioly Ethnomedicine, vol. 14, $\mathrm{n}^{\circ}$ 1, p. 20-33.

Vernon D., 1993. Choses de la forêt. Identité Thérapie Chez Noirs Marrons Ndjuka Surinam ; In Jolivet M-J, Rey-Hulman D., Jeux d'identités. Études comparées à partir de la Caraibe. Paris, L'Harmattan, p. 261-281.

Vernon D., 1992. Les représentations du corps chez les Noirs Marrons Ndjuka du Surinam et de la Guyane française. Paris, Editions de l'ORSTOM, 95 p. 
Voeks R.A., 2007. Are women reservoirs of knowledge? Gender, ethnobotany and globalization in northeast Brazil. Singapore Journal of Tropical Geography, vol. 28, nº 1, p. 7-20.

Volpato G., Godinez D., Beyra A., 2008. Migration and ethnobotanical practices: the case of tifey among haitians immigrants in Cuba. Human Ecology, vol. 37, n 1, p. 43-53.

Vossen T., Towns A., Ruysschaert S., Quiroz D., van Andel T., 2014. Consequences of the transAtlantic slave trade on medicinal plant selection: plant use for cultural bound syndromes affecting children in Suriname and Western Africa. PloS One [En ligne], $n^{\circ} 11$. https://doi.org/ 10.1371/journal.pone.0112345

Wehi Priscilla M., Wehi William L., 2010. Traditional Plant Harvesting in Contemporary Fragmented and Urban Landscapes. Conservation Biology, vol. 24, nº 2, p. 594-604.

Wiel M., 1999. La transition urbaine : villes bonnes à vivre, villes invivables. Revue semestrielle MAUSS, vol. 39, $\mathrm{n}^{\circ} 14$, p. 175-184.

Wooding C.J., 1979. Traditional Healing and Medicine in Winti: A Sociological Interpretation. African Issues, vol. 9, $n^{\circ} 3$, p. 35-40.

Zeder M.A., 2006. Central questions in the domestication of plants and animals. Evolutionary Anthropology. Issues, News, and Reviews, vol. 15, n 3, p. 105-117.

\section{NOTES}

1. According to P. Descola, in the Western world it is the landscape of Roman times and the values associated with it that have drawn this dividing line between the wild and the domesticated, something that we still see today (Descola, 2004a).

2. Until $1^{\text {st }}$ July 2017 , when the decrees implementing the law on research into traditional knowledge associated with genetic resources came into force. Data collected after this date relates only to the name of the species collected, and does not state their therapeutic indications or where they were collected.

3. A few wooded knolls are dotted across the urban landscape in the city of Cayenne.

4. The Guianese term for wetlands and flooded savanna.

5. Meaning born as a foreigner abroad and resident in France (Hurpeau, 2012).

6. From its name in the Haitian vernacular (and also known as yesken). But Guianese Creoles call it sorosi, the Businenge call it busi sopolopo and Creoles in the Antilles call it paroka or manjé kouli.

7. In Guiana, a bitter cup is an alcoholic medicinal beverage made from a blend of plants - often bitter - macerated in rum.

8. Passed on particularly in the Amazon form of "ceremonial friendships" described by P. Descola (1993).

9. We talk here about booko fu ketee, "collecting for the ketee" (from the English word kettle, used by Businenge women to boil up the plants for use in bathing).

10. This is without doubt one of the least-known Afro-American religions (van Andel et al., 2013), blending African and European beliefs with numerous Amerindian features (ceremonial objects, divinities, ritual flora, etc.).

11. Some recent examples of pre-domestication have nevertheless been found, two varieties in particular: Begonia glabra Aubl. (koo ati) and Renealmia alpinia (Rottb.) Maas (masusa).

12. Note that for the Ndjuka, some forest plants are considered sacred - and, in extenso, magical because they helped their fugitive forebears to survive (van Andel et al., 2013).

13. Moreover, use of the group's own social order when considering the relationships between non-humans, as suggested by P. Descola (2001), comes into play here because some particularly 
important plants are considered to be the kapiten of plants (Fleury, 2015), a reference to the kapiten (chiefs) who are the heads of Businenge konde ("large villages") (Collomb \& Jolivet, 2008). 14. Among whom Descola describes segmentation of space into shrinking socialisation sectors.

15. M. Lenaerts also distinguishes between three concentric circles: "the furthest", where the most "powerful" plants used by shamans are found, "the nearest", where domesticated plants are found, and the "intermediate area", where the most useful varieties growing on fallows and in the secondary forest are found.

16. Looking at the approach taken by P. Clastres (1972), among Maroons too there is "a masculine and a feminine space, defined respectively as the forest where the men go to hunt, and the settlement, which is the women's domain".

17. And furthermore, Amerindians often sow particular plants around their dwellings specifically to ward off evil spirits (Valadeau, 2016).

18. Plants which grow in an environment adapted by humans (Godinho, 1984).

19. Among the Ndjuka, this is formally forbidden: menstruating women must not touch medicinal plants, otherwise they will lose their effectiveness (Vernon, 1992).

20. Also much used by rural Creole populations, who called it yanman.

21. Self-sown plants are wild plants which grow among crops (Godinho, 1984).

22. This latter example, according to the classification by Zeder (2006), is typically in the category of domesticated vegetable varieties. According to the aforementioned author, these are indigenous plants which are cultivated more or less successfully around dwellings.

23. From the English bitter. As we have seen, these are alcoholic medicinal beverages made of bitter leaves, drunk by Ndjuka men.

24. Winti means Afro-Surinamese religious beliefs.

25. One of the people whom we interviewed, a vehicle owner, told us that his collection points are located in the different districts that he habitually traverses, and are not necessarily connected to each other in terms of spatial distribution: it makes no difference to him, he gathers from the neighbourhood where he goes to work, or visits friends, or plays football, or where he takes his children to school, etc.

26. Literally, "collection for personal hygiene".

27. In other contexts, particularly in towns in the north, we could undoubtedly round off these reasons for medicinal plant collection with other purposes, such as collection for pleasure or for teaching.

\section{ABSTRACTS}

The gathering of medicinal plants in French Guiana is a relatively unknown practice, underestimated and often perceived as an anecdotic or insignificant one. However, everyday people can be seen harvesting plants on the road sides, for their own needs or in small proportions, for selling. This paper aims to characterise these medicinal plants' collection practices, their diversity and their relevance for questioning the functioning of societies, which are subjected to rapid transformations and are therefore designed here as "transitional". Through two case studies, one on urban collection in Cayenne city and one in the rural area along the lower Maroni River, this paper analyses the connection between societies, nature and urban dynamics. By observing the socio-cultural specificities influencing collection modes, we 
propose a conceptualization scheme of collection practices, through the explanatory concepts of heterogeneity and purpose.

\section{INDEX}

Keywords: Collection, medicinal plant, French Guiana, Businenge

Subjects: Sur le Champ - Sur le Terrain

\section{AUTHORS}

\section{MARC-ALEXANDRE TAREAU}

Marc-Alexandre Tareau, tareau.marc.alexandre@gmail.com, is a Ph.D. student at Guiana University. He recently published:

- Tareau, M.-A., Palisse, M., Odonne, G., 2017. As vivid as a weed... Medicinal and cosmetic plant uses amongst the urban youth in French Guiana. Journal of Ethnopharmacology, n 203, p. 200-213.

- Tareau M.A., Odonne G., Fozzani J., Palisse M., 2019. Pratiques de cueillette urbaine des plantes médicinales dans l'île de Cayenne. Rennes, Presses Universitaires de Rennes, sous presse.

\section{LUCIE DEJOUHANET}

Lucie Dejouhanet, lucie.dejouhanet@orange.fr, is a senior Lecturer at Université des Antilles, AIHP-GEODE EA 929. She recently published:

- Dejouhanet L., 2014. Supply of Medicinal Raw Materials. The Achilles Heel of Today's Manufacturing Sector for Ayurvedic Drugs in Kerala. Asian Medicine, vol. 7, n 3, p. 206-235. - Dejouhanet L., 2014. Secteur informel et réseaux de commercialisation des plantes médicinales au Kérala (Inde). Économie rurale, $n^{\circ} 343$, p. 53-70.

- Dejouhanet L., 2017. Tourism in the mountains of Central Kerala (South India): at the Crossroads of attitudes toward forest populations. Journal of Alpine Research, vol. 105, n 3 / Le tourisme dans les montagnes du centre du Kérala (Inde du Sud) : à la croisée des regards posés sur les populations forestières. Journal de Géographie Alpine, vol. 105, nº 3.

\section{GUILLAUME ODONNE}

Guillaume Odonne, guillaume.odonne@cnrs.fr, est Research fellow at CNRS, and member of research unit LEEISA. He recently published:

- Odonne G., Molino J.-F., 2018. Écologie historique amazonienne, une interdisciplinarité nécessaire quand l'archéologue est perdu dans les bois... Les nouvelles de l'archéologie, $\mathrm{n}^{\circ} 152$, p. 11-15.

- Ogeron C., Odonne G. et al., 2018. Palikur traditional roundwood construction in Eastern French Guiana: ethnobotanical and cultural perspectives. Journal of Ethnobiology and Ethnomedicine [En ligne]. https://ethnobiomed.biomedcentral.com/articles/10.1186/s13002-018-0226-7

- Tareau, M.-A., Palisse, M., Odonne, G., 2017. As vivid as a weed... Medicinal and cosmetic plant uses amongst the urban youth in French Guiana. Journal of Ethnopharmacology, n² 203, p. 200-213.

\section{MARIANNE PALISSE}

Marianne Palisse, marianne.palisse@univ-guyane.fr, is a senior Lecturer at Guiana University, LEEISA, USR 3456. She recently published:

- Tareau, M.-A., Palisse, M., Odonne, G., 2017. As vivid as a weed... Medicinal and cosmetic plant uses 
amongst the urban youth in French Guiana. Journal of Ethnopharmacology 203: 200-213.

- Palisse, Marianne, 2016. Les pratiques agricoles des migrants haïtiens en Guyane : entre insertion et stigmatisation. In Collomb G., Mam Lam Fouck S., Mobilités, ethnicités et diversité culturelle. La Guyane entre Surinam et Brésil, Ibis Rouge, pp. 189-206.

- Palisse, Marianne, 2014. La Faculté d'Ethnologie de l'Université d'État d'Haïti : des projets de Price-Mars et de Roumain à la réalité des années 2000. In Byron J.P. (dir.), Production du savoir et construction sociale. L'ethnologie en Haïti, Presses de l'Université de Laval / Éditions de l'Université d'État d'Haïti, pp. 83-98.

\section{CLARISSE ANSOE}

Clarisse Ansoe, ansoe.clarissemana@gmail.com, a student at Guiana Univer and she is an interpreter in nenge tongo language. 